UDC $621.314 .224 .014 .1: 621.315 .052 .3$

\title{
変流器の三相接続における零相回路の 特性と残留電流計算法
}

\author{
正員坪内伝次 (東芝) \\ 正上西徹 (東芝)
}

\section{1.はしがき}

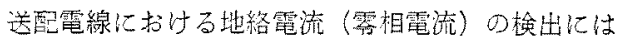
雾相变流器あるいは, 变流哭 (CT) 個三相接続し た場含の零相回路（残留回路又心閏放三角結線した三 次回路）などが用いられる。

これらの检出方法は，古くから用いられているが， その特性に関京る報告は零相变流器に見るべきすのが あるが\{1)\{2\}，CTを3個三相接続したときの零相回路 については，零相電流特性について見られる程度であ $b^{(3)}$ 。

今回，零相回路の特性（雾相電流特性，牫留電流特 性）在明らか儿すへくく、検討を行なった。特に残留電 流について，乙の発生原因，二次負担の不平衡による 影敬，残留回路上三次回路の残留電流の大きさの関

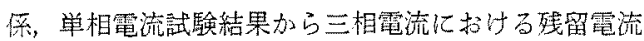
の推定,などを考察した。

需相变流器の特性については，すてに規格化(JEC190，1974）され，許窝差，残留電流の隄度，試験法 などが明記されている。しかるに，露相回路の特性に ついては規定がな，組合せるCT 個々について規定 されている程度でする。この問題は JEC-190 の密淁 に際しても議題となったが椮討不十分のため規格化は 是选秃ている。

本文の检討結果により，民机らの規格化の一つの端 緒が得られたものと㿾ずる。しかし，三次雾相回路の 場合て二次負担平衡时の規格化には問題加残る。

本文に用いる主な記号は次のとおりである。

Characteristics of the Zero Phase Sequence Circuit in Three Phase Current Transformer Connection and a Method for Calculation of Residual Currents. By Denji Tsubouchi, Member \& Touru Kaminishi, Member (Tokyo Shibaura Electric Co. Ltd, Hamakawasaki Works)

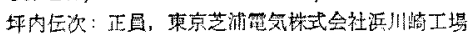

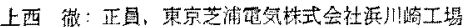

\section{論 文 \\ 52-B 6}

$v:$ 電厌

$I$ ：一次電流 $\left(I^{I}\right.$ : 正相分・逆相分, $I_{0}$ ：雾相分 $)$

$i:$ 二次電流 ( $i^{\prime}$ : 正相分, 逆相分)

$i_{\mathrm{f}}$ : 励磁電流 (二次換算)

$i_{0}$ : 雾相回路汇流吅る電流

$i_{0}^{\prime}: i_{0}$ 中のI I による成分

$i_{R}$ : 残留電流

$Z_{B}, Z_{R}$ ：それぞれ二次，零相回路の負担インピーダ ンス

$Z_{2 l}, Z_{3 l}:$ 二次, 三次の屚れインピーダンス

$Z_{B l}: Z_{B} \leq Z_{2 i}$ ○和

$M:$ 励磁ヘンピーダンス (二次換算)

$M_{s}$ : 各 CT $M$ の算術平均值

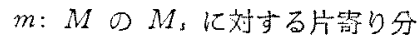

$K$ : 卷数比 $\left(K=T_{2} / T_{1}, K_{1}=T_{2} / T_{3}\right)$

a: $e^{j 1200}$

添字 $a, b, c, n$ : 相别, $n$ は $a, b, c$ 一一般形

添字 2，3：零相回路 (残留回路, 三次回路) の別

\section{2. 特 性 式}

〈2.1〉残留回路の場合 残留回路は CT 3 個在 第1图のように三相接綂して得ら水る。但し，図は一 次側諸量老二次侧に撸算して示した回路で方る。困上

り，CTaについて次式地成立つ。

$$
\begin{aligned}
& K v_{1 a}=K I_{a} Z_{1}-i_{a} M_{a} \ldots \ldots \ldots \ldots \ldots \ldots \\
& v_{2 a}=I_{a} M_{a} / K-i_{a} Z_{2}=i_{a} Z_{B a}+i_{02} Z_{R 2}
\end{aligned}
$$

一般に CT の特性を解析するには二次側のみを考察 すれば十分である。(2)式より

$$
I_{a} M_{a} / K=i_{a}\left(Z_{2}+Z_{B a}\right)+i_{02} Z_{R 2}
$$

$Z_{B l a}\left\{=\left(Z_{2}-M_{a}\right)+Z_{B a}\right]$ 在用いると（3)式は次式 の上うに書觔えられる。

$$
I_{a} M_{a} / K=i_{a}\left(Z_{B l a}+M_{a}\right)+i_{02} Z_{R 2}
$$




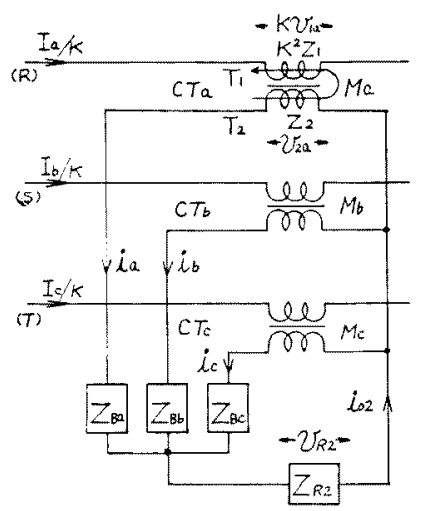

第 1 这 残留回路の接続

Fig. 1. Connections of residual circuit.

$$
\left.\begin{array}{l}
C T_{b}, C T_{b} \text { について屯同様に } \\
I_{b} M_{b} / K=i_{b}\left(Z_{B t b}+M_{b}\right)+i_{02} Z_{R 2} \\
I_{c} M_{c} / K=i_{c}\left(Z_{B l c}+M_{c}\right)+i_{02} Z_{R 2}
\end{array}\right\}
$$

又, 第 1 図上り

$$
\left.\begin{array}{l}
I_{a}+I_{b}+I_{c}=I_{0} \\
i_{a}+i_{b}+i_{c}=i_{02}
\end{array}\right\} .
$$

且 $\supset$,

$$
\begin{aligned}
& M_{s}=\left(M_{a}+M_{b}+M_{c}\right) / 3 \\
& M_{a}=M_{s}+m_{a} \\
& M_{b}=M_{s}+m_{b} \\
& M_{c}=M_{s}+m_{c}
\end{aligned}
$$

上置く。この上き次の関係加ある。

$$
m_{a} \div m_{b}+m_{c}=0
$$

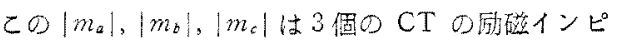
一ダンスのばらつきを示し，一般のCTては $\left|M_{s}\right|$ に 比数して小むい。

(4)，(5)式の車正の和をとり，(6)，(7)，(8)式

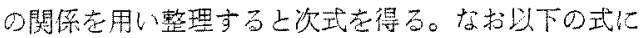

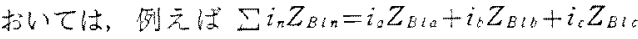
のように表的すすとする。

$$
\begin{aligned}
I_{0} M_{n} K= & \left.i_{n} M_{s}+3 Z_{K 2}\right)+\sum i_{n} Z_{Q n n} \\
& -\sum\left(I_{n} / K-i_{n}\right) m_{n} \ldots \ldots \ldots
\end{aligned}
$$

一般の CT 批ては，(4)，(5)式上り

$$
\begin{aligned}
I_{n} / K-i_{n}= & i_{e n}=\left(i_{n} Z_{E l n}+i_{02} Z_{R 2}\right) / M_{n} \\
\fallingdotseq & \left(i_{n} Z_{B l n}+i_{02} Z_{R 2}\right) \\
& \times\left(1-m_{n} / M_{s}\right) / M_{s} \ldots \ldots \ldots
\end{aligned}
$$

(10)式より $\sum\left(I_{n} / \alpha-i_{n}\right) m_{n}$ 老求

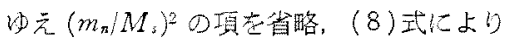

$\sum\left(I_{n} / K-i_{n}\right) m_{n}=\sum i_{n} Z_{B i n} m_{n} / M_{s}$

(11)式を(9)式化代入整理すると

昭 $52-1$

$$
\begin{aligned}
\frac{I_{o} M_{s}}{K^{-}}= & i_{02}\left(M_{s}+3 Z_{R 2}\right) \\
& +\sum i_{n} Z_{B ! n}\left(1-\frac{m_{n}}{M_{s}}\right)
\end{aligned}
$$

一方， $i_{n}=i_{n}{ }^{t}+i_{02} / 3$ ，又，一般に $i_{n}{ }^{\prime} \fallingdotseq I_{n}{ }^{\prime} / K$ と㧧 るから，乙机ら老用いて(12)式は次式のように替替 无ら机る。

$$
\begin{aligned}
\frac{I_{0} M_{s}}{K^{-}}= & i_{02}\left\{M_{s}+3 Z_{R 2}\right. \\
& \left.+\frac{1}{3} \sum Z_{B ! n}\left(1-\frac{m_{n}}{M_{s}}\right)\right\} \\
& +\sum \frac{I_{n}^{\prime}}{K} Z_{B ! n}\left(1-\frac{m_{n}}{M_{s}}\right)
\end{aligned}
$$

丈, $I 0 / K r-i_{02}=i_{e 2}$ とおく上(13)式より

$$
\begin{aligned}
i_{e 2} M_{s}= & i_{02}\left\{3 Z_{R 2}+\frac{1}{3} \sum Z_{B l n}\left(1-\frac{m_{n}}{M_{s}}\right)\right\} \\
& +\sum \frac{I_{n}^{\prime}}{K} Z_{B l n}\left(1-\frac{m_{n}}{M_{s}}\right) \ldots \ldots \ldots(1
\end{aligned}
$$

(13)，(14)式仿残留回路の特性式である。

〈2.2〉三次回路の場合 三次回路は第 2 图の上 うに三次卷線在開放三雇結線して得られる。但し，图 は一次，三次回路の諸量を二次侧に換算して示した回 路てある。図上り CTaについて次式を得る。

$$
\begin{aligned}
& K v_{1 a}=K I_{a} Z_{1}-\left(i_{a}+i_{03} / K_{1}\right) M_{a} \\
& \begin{aligned}
v_{2 a} & =\left(I_{a} / K-i_{03} / K_{1}\right) M_{a}-i_{a} Z_{2} \\
\quad & =i_{a} Z_{E a}+v_{k 2} \ldots \ldots \ldots \ldots \ldots \ldots \ldots
\end{aligned} \\
& K_{1} v_{3 a}=\left(I_{a} / K-i_{a}\right) M_{a}-K_{1} i_{03} Z_{3} \\
& I_{a} / K=i_{a}+i_{03} / K_{1}+i_{e a} \ldots \ldots \ldots \ldots
\end{aligned}
$$

又, 国の回路上り

$$
\begin{aligned}
& I_{a}+I_{b}+I_{c}=I_{0} \\
& i_{a}+i_{b}+i_{c}=0 \\
& v_{3 a}+v_{3 b}+v_{3 c}=i_{03} Z_{R 3}
\end{aligned}
$$

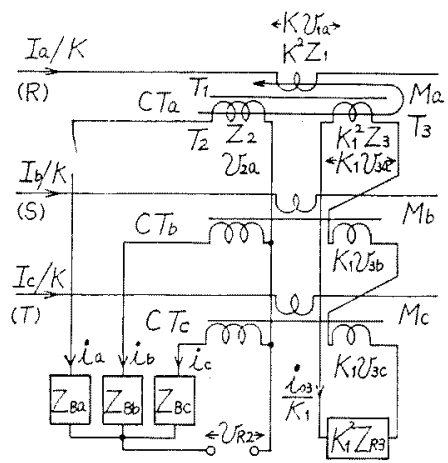

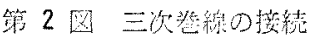

Fig. 2. Connections of tertiary windings. 
三次回路の特性検討には三次側のみ考慮すればよ

い。(17)式上り次式在得る。但し,

$$
K_{1}^{2} Z_{3 l a}=K_{1}^{2} Z_{3}-M_{a}
$$

と就く。

$$
\begin{aligned}
I_{a} M_{a} / K= & K_{1} v_{3 a}+\left(i_{a}+i_{03} / K_{1}\right) M_{a} \\
& +K_{1} i_{03} Z_{31 a} \ldots \ldots \ldots \ldots \ldots
\end{aligned}
$$

同様に $C T_{b}, C T_{c}, k \supset W て$

$$
\begin{aligned}
I_{b} M_{b} / K= & K_{1} v_{3 b}+\left(i_{b}+i_{03} / K_{1}\right) M_{b} \\
& +K_{1} i_{03} Z_{3 i b} \\
I_{c} M_{c} K= & K_{1} v_{3 c}+\left(i_{c}+i_{03} / K_{1}\right) M_{c} \\
& +K_{1} i_{03} Z_{3 i c}
\end{aligned}
$$

(20)，(21)式の雨辺の総和在取り，(7)，(8)，(19)

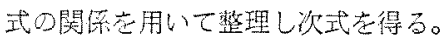

$$
\begin{aligned}
I_{0} M_{s} / K= & 3 i_{03} / K_{1}\left\{M_{s}+\left(K_{1}^{2} / 3\right)\left(Z_{R 3}\right.\right. \\
& \left.\left.+\sum Z_{3 i n}\right)\right\}-\sum m_{n}\left(I_{n} / K-i_{n}\right)
\end{aligned}
$$

(22)式中右辺第2 項は，(8)，(18)式により

$$
\sum m_{n}\left(I_{n} / K-i_{n}\right)=\sum m_{n} i_{i n}
$$

(16)，(18)式の関係より $i_{e n}$ を求め，(7)，(8)式の 関係と $m_{n}$ 公M $M_{s}$ とすると

$$
i_{e n}=\left(i_{n} Z_{B l n}+v_{R 2}\right) / M_{S}
$$

ゆえに,

$$
\sum m_{n} i_{e n}=\sum i_{n} Z_{B i n} m_{n} / M_{s}
$$

(22)式江(24) 式を代入し，且つ $i_{n} \fallingdotseq I_{n}^{\prime} / K$ を用いて 次式加得吕れる。

$$
\begin{aligned}
\left(I_{0} / 3 K\right) M_{s}= & \left(i_{03} / K_{1}\right)\left\{M_{s}+K_{1}{ }^{2}\left(Z_{R 3}\right.\right. \\
& \left.\left.+\sum Z_{3 l n}\right) / 3\right\}-\left(1 / 3 M_{s}\right) \\
& \times \sum\left(I_{n^{\prime}} / K\right) Z_{B \ln } m_{n} \ldots
\end{aligned}
$$

又,

$$
I_{0} / 3 K-i_{03} / K_{1}=i_{\varepsilon 3} / K_{1}
$$

七おく上

$$
\begin{aligned}
\left(i_{e 3} / 3 K_{1}\right) M_{s}= & \left(i_{03} / K_{1}\right) K_{1}{ }^{2}\left(Z_{R 3}+\sum Z_{3 i n}\right) / 3 \\
& -\left(1 / 3 K M_{s}\right) \sum I_{n}{ }^{\prime} Z_{B l n} m_{n}
\end{aligned}
$$

(25)，(26)式は三次回路の特性を示す式である。

\section{3. 特性 と実験結果}

〈3.1〉零相電流特性 $i_{02}, i_{03}$ は土てれぞれ (13)， (25)式加ら次式で表わされる。

残留回路の場合

$$
i_{02}=\frac{\frac{I_{0}}{K}-\frac{1}{M_{s}} \sum\left(\frac{I_{n}}{K}\right) Z_{B l n}\left(1-\frac{m_{n}}{M_{s}}\right)}{1+\frac{3 Z_{R 2}}{M_{s}}+\frac{1}{3 M_{s}} \sum Z_{B l n}\left(1-\frac{m_{n}}{M_{s}}\right)}
$$

三次回路の場合

$$
i_{03}=\frac{K_{1} \frac{I_{0}}{K}+\frac{1}{M_{s}^{2}} \sum\left(\frac{I_{n}^{\prime}}{K}\right) Z_{B i n} m_{n}}{1+\frac{K_{1}^{2}}{3 M_{s}}\left(Z_{R 3}+\sum Z_{3 i n}\right)} .
$$

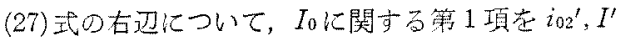

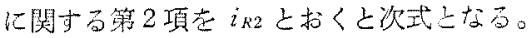

$i_{02}=i_{02}{ }^{\prime}+i_{R 2}$

この式から，雾相三次電流特性は $i_{02}^{\prime}$ 上 $i_{R 2}$ のベク トル和として現われ，Ioと $I^{\prime}$ との位相関係で程々の 值上なるとと加知られる。且つ，i $020 I_{0}$ に対する就 差は $M_{s}$ 方大きい程, $Z_{R 2}, Z_{B 1 n}$ 加 $M_{s}$ に比して小d い程小さくなる。

又， $I^{\prime} \neq 0$ の場合には，各 CT の鉄心は $i^{\prime}\left(\fallingdotseq I^{\prime} / K\right)$ し $Z_{B t}$ などによる誘起電压に対応して磁化さ机てい るととになる。この状態に扔いて Io 加流扎ると, を のI $I_{0}$ にる鉄心磁化の動作点はI'により予め磁化 されている分だけ高く，Zれだけ透磁率の高い点で動 作し見挂け上 $M$ ：が大きくなる。侻って，I0-i02 特性 は，たとえ $i_{R 2}=0$ であっても， $I^{\prime}=0$ の場合に比較 して誤差が小さ良好となる。このことは一般の子磁 化CTと同し動作で南り， $I^{\prime} \neq 0$ ○場合の $I_{0}-i_{02}$ 特性 はその予磁化 CT の特性と同し傾问走す。

これらの特性傾问は $i_{03}$ ( (28)式〕についても全く同 様であるが，三次の巻数が少ないため，予磁化や鱼担 の影響は i02 の場合に比して大きい。

次に，雾相電流の特性傾问を実駼結果に上り示す。 試料仗，定格加 $5 / 5 \mathrm{~A} ， 40 \mathrm{VA}, 50 \mathrm{~Hz} ， T_{1}=T_{2}=200$ 回， $T_{3}=19$ 回，K=1，K1=200/19@もの3 個で， 励磁電流のばらつき加割合に大きい組合世である。

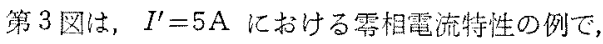

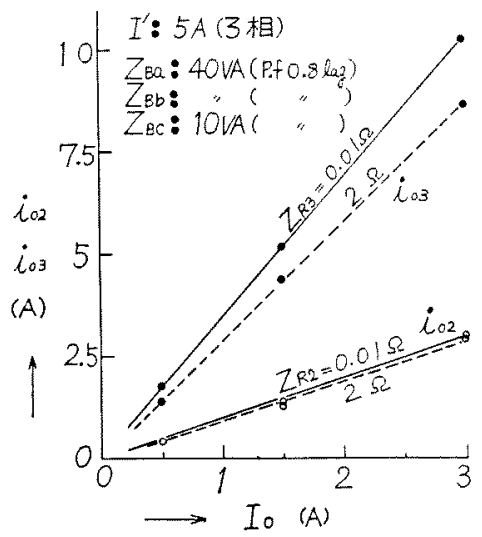

第 3 四 害相電法特性

Fig. 3. Characteristics of zero phase sequence current. 


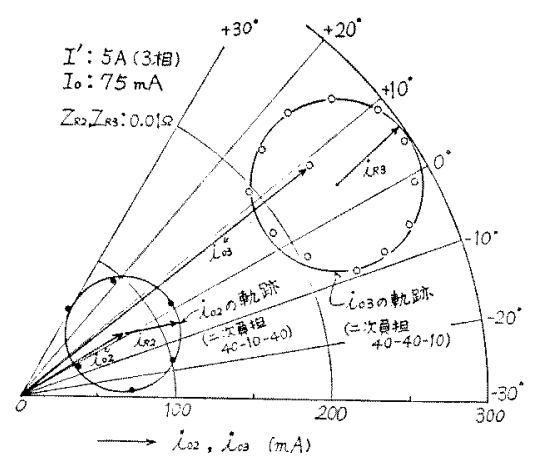

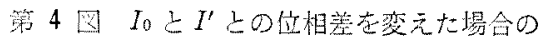
$i_{02}, i_{03}$ ○斬跡

Fig. 4. Loci of $i_{02}$ and $i_{03}$ when the phase differences between $I_{0}$ and $I^{\prime}$ are changed.

$i_{02}, i_{03}$ 结结添 $I_{0}$ 红比例する。負担 $2 \Omega$ (50VA 相当) てはその比例性はむるが大きさは小さくなる。その傾 向は巻数の少ない $i_{03}$ の方が大きい又，てれらの特

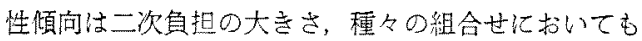
同様でる。

第4四は(29)式の状況を大きく示ずた，100小さ い領域で $I_{0}$ 上 $I^{\prime}$ の位相を 360 度変化させて測定し 必結果であり，i02，i03 の軌跡加乞れぞれ $i_{R 2}, i_{R 3}$ を半 径亡する円となっている。図中 $i_{02}{ }^{\prime \prime}, i_{03}{ }^{\prime \prime}$ は $I^{\prime}=0$ の 場合の值である。この図で $i_{03}{ }^{\prime \prime}$ の頂点は $i_{K 3}$ の円の

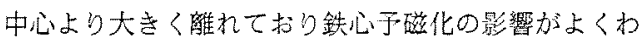
加。なお，第 3 図ては不明確でるが，第 4 図加ら
$I_{0}$ の小さい領域では $I_{0}$ と $I^{\prime}$ の位相によって $i_{0}$ は異 なった値をとり， $I_{0}-i_{0}$ 特性注種々の曲線となること が知られる。

$\langle 3 \cdot 2\rangle$ 残留電流特性 残留電流は $I_{0}$ 炱含まな いI，すなわ方 $I^{\prime}$ を流した場合に雾相回路に流れる 電流のことで，その式は (27)，(28)式より $I_{0}=0$ 上お いて得られる。すな⿰力口。

$$
i_{\text {R2 }}=-\frac{\frac{1}{M_{s}} \Sigma\left(\frac{I_{n}{ }^{\prime}}{K}\right) Z_{B \ln }\left(1-\frac{m_{n}}{M_{s}}\right)}{1+\frac{3 Z_{R 2}}{M_{s}}+\frac{1}{3 M_{s}} \sum Z_{B l n}\left(1-\frac{m_{n}}{M_{s}}\right)}
$$

$$
i_{R 3}=\frac{K_{1}}{3} \frac{\frac{1}{M_{s}^{2}} \Sigma\left(\frac{I_{n}{ }^{\prime}}{K}\right) Z_{B / n} m_{n}}{1+\frac{K_{1}{ }^{2}}{3 M_{s}}\left(Z_{R 3}+\sum Z_{3 / n}\right)}
$$

上式より，残留電流の発生原因は， $i_{\kappa 2}$ の場合 $Z_{B b}$ の不平衡上 $m$ の存在, $i_{R 3}$ の場合 $m$ の存在であるこ とが知られる。それらの大きさは， $I^{\prime}, m, Z_{B t}$ 及びを の不平衡度の大きい程, 又 $M_{s}$, 零相回路負担か心さ いほど大きくなる。

特に， $i_{R 2}$ は $Z_{B}$ の不平衡によっても発生する点が 注目さ机る。し加も一般 CTては $m / M$ ，は小さい試 料では 0.2 以下）加 $i_{R 2}$ はほぼ $Z_{B}$ ○不可衡度で左 右されるとみてよい。

次化，前記試料伅よる実験結果老す。第 5 図は各 種負担の組合せによる $i_{R 2}, i_{R 3}$ の测定結果である。 $i_{R_{2}}$

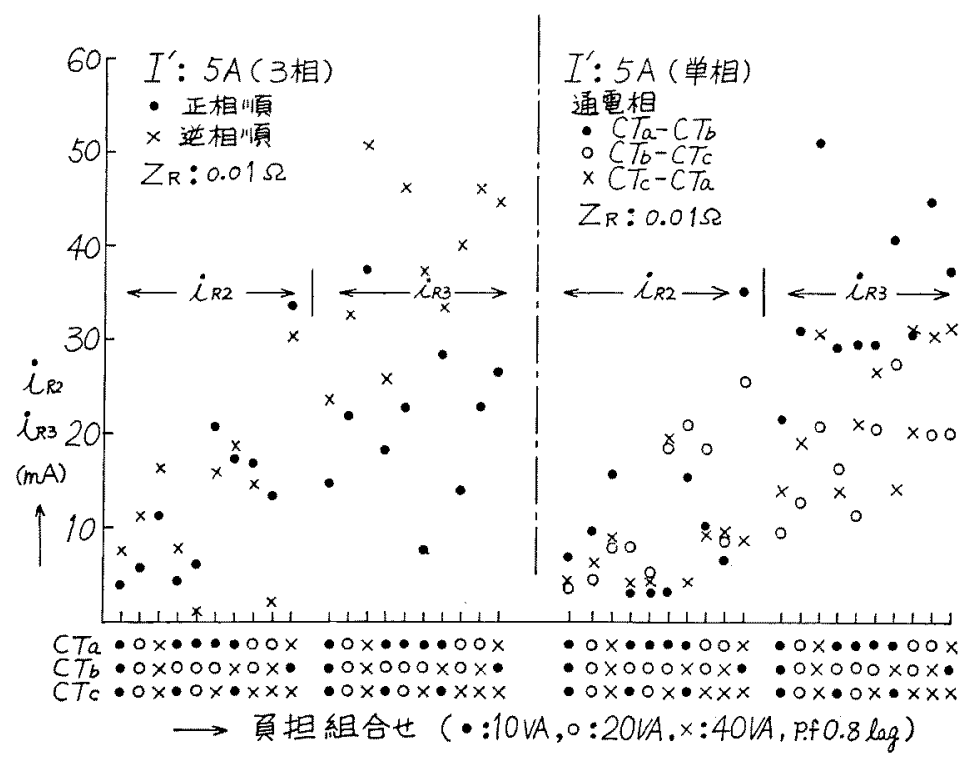

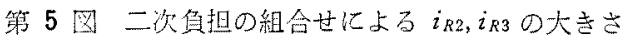

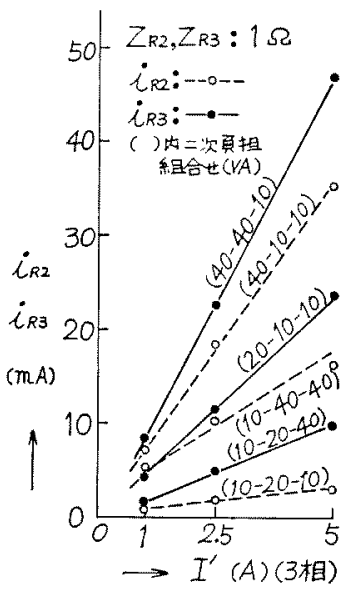

筑 6 图 $i_{K 2}, i_{K 3}$ ○電流特性 Fig. 6. Variations of $i_{R 2}$ and $i_{k 3}$ with the primary currents.

Fig. 5. Magnitude of $i_{R 2}$ and $i_{R 3}$ with the various secondary burdens. 昭 $52-1$ 


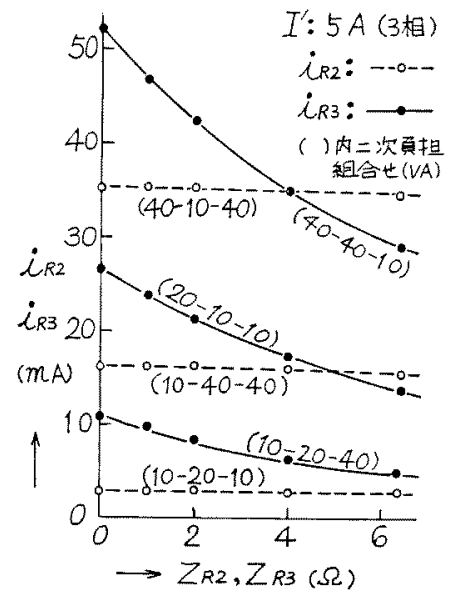

第 7 四 $i_{R 2}, i_{R 3}$ の雾柏負担特性

Fig. 7. Variations of $i_{R 2}$ and $i_{R 3}$ with the zero phase burdens.

は負担平衡の場合に小さく，不平衡度が大きくなると

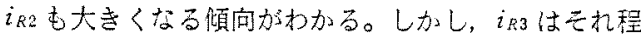
明確でない。又三相（正・逆相順）電流，単相営流そ れぞれの值の間にも一定の㑯向はない。これらは組合 せるCTによって定るるものである。

第6罒は電流特性で $I^{\prime}$ に比例することがわかる。

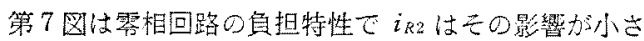
いが， $i_{R 3}$ は大きい。頓问としては負担の增加て減少 する万向にある。

$\langle 3 \cdot 3\rangle \boldsymbol{i}_{R 2}$ 上 $\boldsymbol{i}_{R 3}$ の関係 組怠せる3個のCTは

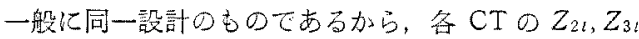
は等しいとみてよい。いま，平衡角担口場合における $i_{R 2}, i_{R 3}$ 在 $(30),(31)$ 上より等出すると次式上なる。

$$
\begin{aligned}
i_{R 2} & =\frac{Z_{B t} \sum I_{n}{ }^{\prime} m_{n}}{K M_{s}\left(M_{s}+3 Z_{R 2}+Z_{B l}\right)} \ldots \ldots \ldots \\
i_{R S} & =\frac{K_{1}}{3} \frac{Z_{B l} \sum I_{n}{ }^{\prime} m_{n}}{K_{1} M_{s}\left\{M_{s}+K_{1}{ }^{2}\left(Z_{R 3} 3+Z_{3 l}\right)\right\}}
\end{aligned}
$$

この雨式に抋いて，分母の $\left(3 Z_{R 2}+Z_{D 1}\right) 上 K_{2}^{2}\left(Z_{R 3}\right.$

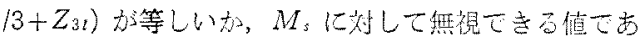
れば， $i_{R 2}, i_{R 3}$ との間には次の関倸がある。

$$
i_{R 3}=\left(K_{1} / 3\right) i_{R 2}
$$

削記試料の湘定結果加ら，iR3の值大(34)式により $i_{R Z}$

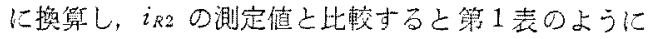
なり，洁代一致することがうかがえる。この結果は， 平衔負担であるしと及び， $Z_{R 2}, Z_{R 3}$ に条件があるが,

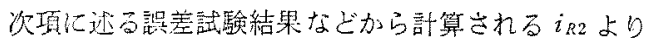
i 3 の大きさが推定できるとと示し有用である。

$\langle 3.4\rangle$ 残留電流之零相分電流上の比継電器と

\begin{tabular}{|c|c|c|c|c|}
\hline \multirow{2}{*}{$\begin{array}{l}\text { 通刑 } \mathrm{CT} \\
\left(i^{\prime}=5 \mathrm{~A}\right)\end{array}$} & \multirow{2}{*}{$\begin{array}{l}\text { 二次色担 (VA) } \\
C T_{a}-C T_{b}-C T_{c}\end{array}$} & \multicolumn{2}{|c|}{$i_{R 3}$} & \multirow{2}{*}{ 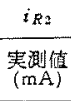 } \\
\hline & & $\begin{array}{l}\text { 寒测健 } \\
(\mathrm{mA})\end{array}$ & $\begin{array}{c}\text { 二次換第值* } \\
i(\mathrm{~mA})\end{array}$ & \\
\hline \multirow{3}{*}{$\begin{array}{l}C T_{a} \\
C T_{b} \\
C T_{c} \\
(3 \text { 相) }\end{array}$} & $10-10-10$ & 14.7 & 4.2 & 4.0 \\
\hline & $20-20-20$ & 22.0 & 6.3 & 5.7 \\
\hline & $40-40-40$ & 37.5 & 10.7 & 10.1 \\
\hline \multirow{3}{*}{$\begin{array}{l}C T_{a} \\
C T_{b} \\
\text { (単相) }\end{array}$} & $10-10-10$ & 21.5 & 6.1 & 6.8 \\
\hline & $20-20-20$ & 32.1 & 9.1 & 9.8 \\
\hline & $40-40-40$ & 52.4 & 14.9 & 15.7 \\
\hline
\end{tabular}

籍 1 表 $i_{R 2}$ 亡 $i_{R 3}$ の閣係

Table 1. Relations between $i_{R 2}$ and $i_{k 3}$.

*:(34)式て换筧 $\left(K_{\mathbf{3}}=200 / 19\right)$

組合せ $I_{0} 0$ の検出感度を上げようとする場合問題とな 万のは $i_{R 2}$ ¿ $i_{02}{ }^{\prime}$ あるいは $i_{R 3}$ 乙 $i_{03}{ }^{\prime}$ の比である。い

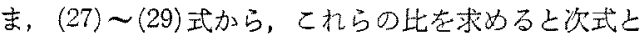
\$。

$$
\left.\begin{array}{l}
i_{R 2} / i_{02}{ }^{\prime}=\sum I_{n}^{\prime} Z_{B l n}\left(1-m_{n} / M_{s}\right) / I_{0} M_{s} \\
i_{R 3} / i_{03}{ }^{\prime}=\sum I_{n} Z_{E l n} m_{n} / I_{0} M_{s}{ }^{2}
\end{array}\right\}
$$

(35) 式において， $m / M_{s}<1$ であるから同一条件に 対しては $i_{R 2} / i_{02}{ }^{\prime} よ り i_{k 3} / i_{03^{\prime}}$ の方汃角担条件にもよる が一般的に小さく有利である。しかし，平衡角担の場 会には

$$
\begin{aligned}
i_{k 2} / i_{02}{ }^{\prime} & =i_{k 3} / i_{03}{ }^{\prime} \\
& =Z_{B L} \sum I_{n}^{\prime} m_{n} / I_{0} M_{s}{ }^{2}
\end{aligned}
$$

となり雨者に差買はなくなる。

又，乙行らの比は，I0一定の骤合，巻数比に無関係

\begin{tabular}{|c|c|c|c|c|}
\hline \multirow{2}{*}{$\begin{array}{l}\text { 二次直担 }(\mathrm{VA}) \\
C T_{n}-C T_{b}-C T_{c}\end{array}$} & \multicolumn{2}{|c|}{ 正 相 順 } & \multicolumn{2}{|c|}{ 逆相 順 } \\
\hline & $i R_{2} / i_{02}{ }^{\prime}$ & ${ }^{i} R_{3} / i_{03}{ }^{\prime}$ & $i_{R_{2} / i_{02}}$ & $i_{R_{3} / i_{09}}$ \\
\hline $10-10-10$ & 0.03 & 0.04 & 0.06 & 0.06 \\
\hline $20-20-20$ & 0.05 & 0.05 & 0.09 & 0.08 \\
\hline $40-40-40$ & 0.08 & 0.09 & 0.13 & 0.12 \\
\hline $10-20-10$ & 0.03 & 0.04 & 0.06 & 0.06 \\
\hline $10-20-20$ & 0.05 & 0.04 & 0.01 & $0.0 ?$ \\
\hline $10-20-40$ & 0.17 & 0.02 & 0.13 & 0.09 \\
\hline $10-40-10$ & 0.14 & 0.07 & 0.15 & 0.08 \\
\hline $20-20-40$ & 0.13 & 0.03 & 0.12 & 0.10 \\
\hline $20-40-40$ & 0.11 & 0.05 & 0.02 & 0.11 \\
\hline $40-10-40$ & 0.27 & 0.06 & 0.24 & 0.11 \\
\hline
\end{tabular}
にI オ゙增加する上大きくなる。すなかち，適用上は 好しくない方向であり，定格電流が大きい場合には， I0の検出感度を下げる必要が生ずるとと當味する。

第 2 表 $i_{R 2} / i_{02}^{\prime}<i_{R 3 / i_{03}}$ O值

Table 2. Values of $i_{R 2} / i_{02}{ }^{\prime}$ and $i_{R 3 / i_{09}}$.

注: 1) $I^{\prime}=5 \mathrm{~A}(3$ 相)

2) $I_{0}$ ⿸ $25 \mathrm{AT}\left(i_{0 z^{\prime}}{ }^{\prime}=0.124 \mathrm{~A}, i_{03}{ }^{\prime}=0.42 \mathrm{~A}\right.$ 相当 $)$ として計算 
前記試料についてこれらの比を計算し，第 2 表化示 シ。この表加も上述のこ上加十分理解てきる。

\section{4. 残留電流の試験}

〈4-1〉試験法残留電流を求如るに活，次の力 法汃ある。

(i) 直接测定

(ii) 間接測定

(1) 誤差測定結果より計算する。

(口) 励磁特性上り計算する。

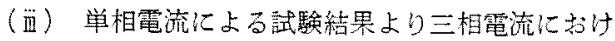
る值を計算する。

(i) 直接測定们ついて

CT 3 個を正規汇接続し，負担，電流など与えられ た条件で $i_{R 2}, i_{R 3}$ 学直接測定するもので，最む正確な 方法である。試験法については特問題となることす ないので省略する。但し，大電流 CT の場合には三相 の試験電源を得ることに困奞な場合が方万う。

(ii) 間接測定について

（イ）誤差試験結果より計算する場合 まず。 $i_{R 2}$ について，(6)式より $I_{0}=0$ のときは次式で表 わされる。

$$
\left.\begin{array}{l}
I_{a}+I_{b}+I_{c}=0 \\
i_{a}+i_{b}+i_{c}=i_{R 2}
\end{array}\right\}
$$

一般代，CIでは $i_{\varepsilon n}=I_{n} / K-i_{n}$ の関原があるから， (37)式上り

$$
i_{R 2}=-\left(i_{c a}+i_{e b}+i_{e c}\right)
$$

CT 個々D誤差 $(\delta=\varepsilon+j \theta)$ 结 $\left(K i_{i} / I\right) \times 100(\%)$ て 与えられるから，(38)式より(39)式を下記の上うに右 辺で制る。ゆえに

$$
i_{R 2}=-\left(I_{a} \delta_{a}+I_{b} \delta_{b}+I_{c} \delta_{c}\right) / 100-K
$$

となり， $i_{R 2}$ が求められる。

$i_{R 3}$ の計算は，平衡負担 $\left(Z_{B 1}\right)$ で， $\left(3 Z_{R 2}+Z_{B 1}\right)$ と $K_{1}{ }^{2}\left(Z_{R 3} / 3+Z_{3 i}\right)$ 加等しいか， $M$ 汶対して十分小さ 以場合（以下 $i_{R 3}$ の特殊条件と言う）にのみ, (34), (39)式を用いて可能である。

（口）励磁特性より計算する場合 $i_{R 2}$ は与え られた筫担，電流条件に招ける各 CI の励磁電流加 ら，(38)式により求方机る。乙机は(1)項上同じで

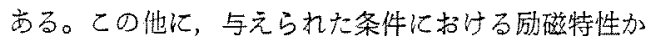
$ら M_{s}, m_{n}$ 求め，(30)式汇より計算できる。との場 合には励磁特性を位相を合めて十分な棈度て剆定する ことが必である。

$i_{R 3}$ は(イ)項上同様， $i_{R 3}$ の特殊条件の場合の及計算 し得られる。
（屰）単相試験結果上り三相特の值の計算 上記 の直接測定に捄いて，三相大電流電源が得られない場 合には，単相大電流に上る試験 (CT 2 個の組合せて $2 \sim 3$ 回）絬果加方三相電流江招ける $i_{R 2}, i_{R 3}$ 加計算で きる。

今, $(30)$ 式において

$$
\begin{aligned}
Q= & -1 / K\left\{M_{s}+3 Z_{R 2}\right. \\
& \left.+\sum Z_{B i n}\left(1-m_{n} / M_{s}\right) / 3\right\} \\
A= & Z_{B i a}\left(1-m_{a} / M_{s}\right) \\
B= & Z_{B i b}\left(1-m_{b} / M_{s}\right) \\
C= & Z_{B i c}\left(1-m_{c} / M_{s}\right)
\end{aligned}
$$

上扮く上，三相平衡電流 $\left(I^{\prime}\right)$ の上き次式上なる。

$$
i_{R 2}=I^{\prime} Q\left(A+a^{2} B+a C\right)
$$

一般代 $m_{n} / M s \leqslant 1$ で苛り，又，平衡真担の場合汇

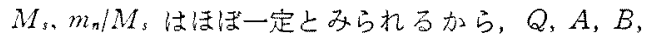
Cはほぼ定数と考えて上い。この上うな形の式に如い ては単相電流試称結果より三相電流時の $i_{R 2}$ 少計算で きる(2)。

すな⿰ち, $C T_{a}-C T$ 。化単相電流 $\left\langle I^{\prime}\right\rangle$ 空流したと きの残留電流を' $i_{R A}, C T_{b}-C T_{c}, C T_{c}-C T_{a}$ のとき之れ それれ $i_{R B}, i_{R C}$ とすると，平衡三相電流 $\left(I^{\prime}\right)$ のときの 残留電流㹥次式で与えられる。なお, 単相試験の場合 においても各 CT の二次側は与えられた条件で三相接 続して置く必要がある。

$$
\left.\begin{array}{ll}
\text { 正相順の場合 } & i_{R 2}=i_{R A}-a i_{R B} \\
\text { 逆相㮌の場合 } & i_{R 2}=i_{R A}-a^{2} i_{R B}
\end{array}\right\}
$$

次代， $i_{R A} ， i_{R B}, i_{R C}$ の大きさのみが測定されたとき は, それらのうちの最大(例えば $\left.i_{R A}\right)$ を基染上し, $b=i_{R B} / i_{R A}, c=i_{R C} / i_{K A}$ を用いて次式で計算できる。

$$
\begin{aligned}
i_{R 2}= & i_{R A}(1 / \sqrt{2})\left\{\left(1+b^{2}+c^{2}\right) / 2\right. \\
& \left. \pm \sqrt{3} \sqrt{4 b^{2} c^{2}-\left(1-b^{2}-c^{2}\right)}\right\}^{1 / 2}
\end{aligned}
$$

上式で， $i_{R 2}$ に2つの值淂られる。これは棏 の正 相順之逆相順の值である。しかし，何机が正相順の值 かは不明である。一般に $i_{R 2}$ はその2値のうち大きい 万が必要であり，相順の区別は必要ない。

$i_{R 3}$ の場合屯平衡電流，平衡負担の場合には (40) 式 と全く同じ形となり，(41)，(42)式により計算できる。 上記 (i) ( iii) の方法により，前記試料の $i_{R 2}, i_{R 3}$ を計算し，実測值と比較した結果を第 3 表化示す。こ の結果加ら， $i_{R 2}$ 及び三相平衡電流，平衡負担に扣け る $i_{R 3}$ は何れの方法によっても実測值とほぼ一致する ことがわかる。参考として，表中（第了表下 3 行）に $i_{K 3}$ の不平衡負担汅打可镇を試算して示したが何れも䒠 
第 3 表 $i_{R 2}, i_{R 3}$ の翆算值と実测值

Table 3. Measured and calculated values of $i_{R 2}$ and $i_{R 3}$.

(恝位：mA)

\begin{tabular}{|c|c|c|c|c|c|c|c|c|c|c|c|}
\hline & \multirow{3}{*}{ 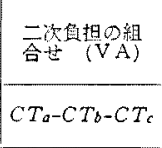 } & \multirow{2}{*}{\multicolumn{2}{|c|}{ 起澌 值 }} & \multirow{2}{*}{\multicolumn{2}{|c|}{ 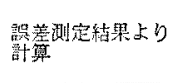 }} & \multirow{2}{*}{\multicolumn{2}{|c|}{ 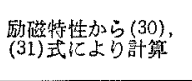 }} & \multicolumn{4}{|c|}{ 単相圾歌結果加ら計算 } \\
\hline & & & & & & & & \multicolumn{2}{|c|}{ 正 相 頑 } & \multicolumn{2}{|c|}{ 逆 相 䐜 } \\
\hline & & 正椙㸟 & 椾相順 & 正相牊 & 逆相順 & 正暞譭 & 逆相酸 & $\begin{array}{l}(41) \text { 证に } \\
23\end{array}$ & $\begin{array}{l}(42)+x \\
28\end{array}$ & $\frac{(41)}{25}$ & $\begin{array}{l}\text { (42) 式に } \\
\text { よる }\end{array}$ \\
\hline \multirow{6}{*}{$i R$} & $10-10-10$ & 4.0 & 7.8 & 4.3 & 7.2 & 4.2 & 6.8 & 3.4 & 4.1 & 8.8 & 7.7 \\
\hline & $20-20-20$ & 5.7 & 11.3 & 5.1 & 10.4 & 5.7 & 9.8 & 5.3 & 7.1 & 12.2 & 10.5 \\
\hline & $40-40-40$ & 10.1 & 16.2 & 9.8 & 14.3 & 10.5 & 15.8 & 9.4 & 11.2 & 17.8 & 16.0 \\
\hline & $10 m-20-40$ & 20.8 & 15.8 & 21.2 & 15.9 & 20.6 & 17.0 & 21.2 & 20.5 & 15.6 & 17.8 \\
\hline & $20-20-40$ & 16.8 & 14.9 & 17.3 & 15.2 & 15.9 & 11.3 & 16.7 & 19.6 & 15.2 & 12.3 \\
\hline & $20-40-40$ & 13.5 & 2,0 & 13.5 & 3.0 & 13.2 & 3.4 & 13.6 & 14.3 & 1.9 & 2.5 \\
\hline \multirow{6}{*}{$i_{R_{3}}$} & $10-10-10$ & 14.7 & 23.6 & 14.3 & 24.0 & 14.0 & 22.5 & 12.9 & 14.0 & 25.0 & 23.7 \\
\hline & $20-20-20$ & 22.0 & 32.6 & 20.1 & 34.7 & 21.0 & 32.7 & 23.8 & 23.9 & 32.3 & 30.3 \\
\hline & $40-40-40$ & 37.5 & 50.9 & 32.7 & 47.6 & 35.0 & 52.7 & 38.5 & 41.0 & 53.3 & 48.0 \\
\hline & $10-20-40$ & 7.3 & 37.2 & - & - & 19.3 & 48.0 & 15.2 & 10.3 & 48.4 & 45.0 \\
\hline & $20-20-40$ & 13.9 & 40.1 & - & - & 12.2 & 52.7 & 10.6 & 11.6 & 45.2 & 46.4 \\
\hline & $20-40-40$ & 22.8 & 46.1 & - & - & 18.8 & 45.5 & 26.2 & 28.2 & 52.9 & 50.4 \\
\hline
\end{tabular}

測值と一致していない。しれは次の理由によると考元 られる。すなわち，不平衡負担のときは $v_{R 2}$ (第 3 㘝 参照)が大きく生じ，とれが三相電流の場合と单相電 流の場合で異なり， $M_{s}, m$ の值を变化させるためと思 われる。

なお，第 3 表方㯗の算相試験結果加ら計算した場合 の相順の区別は実测値と比較し，推定して示したもの 厄ある。

\section{5.むすび}

CT 3 個を三相接続し，その残留回路あるいは三次 巻線孛開放三角結線した回路で構成する零相回路につ いて, 露相電流特性, 残留電流特性を解析した。その 結果次のことが明らかとなった。

雾相電流特性は, 雺相二次電流乞残留電流のベクト ル和よなる。且つ予磁化鉄心を用いた CT のような特 性を示す。

残留電流の発生原因は，CTに関しては使用状態に おける各 CT の励磁インピーダンスのばらつきによ る。特に， $i_{R 2}$ の場合に梳，二次負担の不平衡も大 な発生原因となり，これが $i_{R 2}$ の大ささを決定する最 大の要团ともなると思われる。一般使用の場合には二 次筫担に極端な不平衡はない上思われるが、できうる
限り平衡するよう困ることが望ましい。

雾相回路負担の影響は巻数の少ない $i_{R 3}$ の方がうけ 易い。

二次負担加平衡し，需相回路負担加一定条件にある 場合には， $i_{R 2}$ と $i_{R 3}$ の間に巻数比に関する一定の関 係がある。

$i_{R 2}$ は間接測定により十分に求められるが， $i_{R 3}$ は二 次平衡負担の場合以外は簡笚に求められない。

$i_{R 2}$ は単相試験結果から三相の場合の值を計算によ って求めるととができる。 $i_{R 3}$ の場合のそれは二次負 担平衙の場合に限られる。与えられたCT(鉄心)にお いて, 一次巻数の变更により定格一次電流を大きくす ると, 一定の $I_{0}$ に対する残留電流の比が小さくなり 場合によっては継電器の $I_{0}$ 設定を大きくする必要が 生ずる。

以上の結果が，零相回路の適用上，保護継電器の電 流設定，あるいは規格化の場合などに役立てば幸であ 尚。

(昭和 50 年 9 月 2 日受付, 同 51 年 6 月 30 日再受付)

\section{文献}

(1) 坪内: 電䞑研報 No. 664 (昭 4i-7)

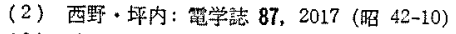

(3) 池㽢: 昭 29 電気三学会速大 No. 77 